2015

\title{
Navigating Uncertainty: The Survival Strategies of Religious NGOs in China
}

Jonathan Tam, University of Oxford

Reza Hasmath, University of Oxford 


\title{
Navigating Uncertainty: The Survival Strategies of Religious NGOs in China
}

\author{
JONATHAN TAM* \& REZA HASMATH** \\ ${ }^{*}$ Department of Sociology, University of Oxford, Oxford, UK; ${ }^{* *}$ School of Interdisciplinary Area Studies, \\ University of Oxford, Oxford, UK
}

\begin{abstract}
This article looks at the strategies religious non-governmental organizations (RNGOs) with strong transnational linkages use to maintain a continued presence in mainland China. It does so by utilizing neo-institutional theory as an instrument for analysis, with an emphasis on outlining the coercive, mimetic, and normative pressures RNGOs face. One of the key findings of the study is that there is creative circumvention of isomorphic pressures by working with local agents, fostering trust with the local government, and keeping a low profile. Moreover, RNGOs dealt with the uncertain institutional environment in China through staff exchanges, denominational supervision, tapping into global platforms, and undergoing a professionalization process.
\end{abstract}

KEY Words: China, NGOs, religion, neo-institutional theory, isomorphism

\section{Introduction}

Though non-governmental organizations (NGOs) in China have been the subject of rising analytical interest in the past few years (e.g. Hasmath \& Hsu, 2008, 2014, 2015a; Hsu, 2011; Shieh, 2013), religious non-governmental organizations (RNGOs) have been largely overlooked. This is partially attributed to the taxonomical difficulties in categorizing whether an NGO is considered religious or not. For instance, the majority of RNGOs are formed under the auspices of transnational religious missions, which make disaggregating their local organizational activities in the nation difficult (Clarke, 2006; Sider \& Unruh, 2004; Thaut, 2009).

Understanding RNGO operations in China is especially limited given China's nascent civil society (Shieh, 2013), corporatist framework to control NGOs (Hsu \& Hasmath, 2013, 2014), the general suspicion towards social organizations with Western origins (Deng, 2010; Madsen, 2010), and shifting socio-political landscapes of religion (Yang, 2012). The Communist Party of China (CPC) has long been wary of the power of religion as a social movement which has historically threatened or toppled Chinese governments and dynasties. ${ }^{1}$ Documents by the CPC's Central Committee (General Office of the

Correspondence Address: Reza Hasmath, Dickson Poon Building, Canterbury Road, Oxford OX2 6LU, UK. Email: rhasmath@gmail.com 
Central Committee of the Communist Party of China, 2011) claim that 'foreign hostile forces' have put even greater emphasis on using religion to infiltrate China to carry out their 'political plot' to 'Westernize and divide China', and further highlight the spread of Christianity as a notable concern. Yang (2012) observes that the socio-political landscape of religion is constantly shifting in China depending on what the government sanctions as legal religious practices. As such, it is prudent that RNGOs adjust their operations to fit the unstable religious landscape. Suffice it to say, religion is perceived by the Chinese state as a potential destabilizing element, viewed as a 'liberalizing' and 'democratizing force'.

The logical syllogism pursued by the state to curb this potential is over-regulation. China does not allow children under the age of 18 to receive religious education in school or in sites of religious practice such as mosques, temples, or churches (Hasmath, 2010). Public sector employees are not allowed to practice a religion (e.g. fasting during Ramadan) or wear religious attire while working. Further, the registration of religious organizations is handled differently than other types of NGOs in China. In general, NGOs should be registered under the Ministry of Civil Affairs (MCA). However, RNGOs are registered and managed under separate organizations, the State Administration for Religious Affairs (SARA) at the central level, and the Religious Affairs Bureau (RAB) at the local level. ${ }^{2}$

Given the difficulty to attain non-profit status, most NGOs that register as businesses still operate and behave as regular NGOs (Simon, 2013). Hasmath and Hsu (2014) maintain that, in order to survive, NGOs have to market themselves as providing essential services to the government to legitimize their existence. Vala (2012) concluded that local governments are amenable to the free resources from religious institutions as long as religious issues are subordinate to the government's goals of stability and economic development. This resonated with Jennifer Hsu's (2012) finding that state-NGO interactions vary according to different layers (e.g. national, municipal, district) and spaces (e.g. Beijing, Xinjiang, Tibet). Furthermore, Deng's (2010) study found that both unregistered NGOs and foreign NGOs are subject to many unspoken rules, resulting in their limited growth due to the NGOs' cautiousness in dealing with this uncertainty.

In other words, we argue that RNGOs not only have to deal with the government's complex corporatist model of handling all NGOs, they need to negotiate the additional complex dimension of religion. Thus, as an organizational category, they encounter challenges and opportunities that are quite different from those encountered by secular NGOs. For example, the religious mission of RNGOs must be retained to stay accountable to donors, yet these RNGOs must exercise the organizational awareness and flexibility observed among other civil society actors.

In spite of this institutional environment, RNGOs are some of the most resilient social organizations outside the party-state structure. They are increasingly prevalent in mainland China, notably in the relatively developed urban cities. This begs the question: What strategies do RNGOs employ to maintain a continued presence in mainland China? Using the concept of isomorphism-embedded in neo-institutional theory-as an instrument for analysis, this article will examine the survival strategies and hidden rules' evangelical Christian RNGOs with strong transnational ties utilize to navigate China's authoritarian, socio-political environment. 


\section{RNGOs as an organizational field}

The term 'religious' in RNGOs requires further elaboration since there is no uniform understanding of what it means. Using Sider and Unruh's (2004) oft-cited typology of religious characteristics in social services, educational organizations, and programmes, religious organizations have varying degrees of religiosity ranging from faith-permeated (whereby the connection with religious faith is evident at all levels of mission, staffing, governance, and support); faith-centred (founded for a religious purpose; remain strongly connected with the religious community through funding sources and affiliation; and require the governing board and most staff to share the organization's faith commitments); faith-affiliated (retain some of the influence of their religious founders, but do not require staff to affirm religious beliefs or practices); faith-background (have a tendency to look and act secular, although they may have a historical tie to a faith tradition); faithsecular partnership (a secular entity joins with one or more congregations or other explicitly religious organization); or secular (have no reference to religion in their mission). While there are competing frameworks in understanding religious institutions, our intention in using this framework is not to critique the typology of religious institutions, but rather to have it serve as a reference in elucidating the centrality of the religious mission to RNGOs. Specifically, its function is twofold: First, it describes the typological category to which our sample RNGOs belong; and second, it highlights how transnational RNGOs adapt to their local contexts depending on whether they originate in North America or China. This will be elaborated further in the article.

Similarly, in Thaut's (2009) typology of Christian faith-based organizations, they vary in the degree of proselytization mixed with humanitarian work. China's constrictive religious environment requires many RNGOs to mitigate their overt religious proclivities and dwell on the humanitarian concerns (Vala, 2012). Transnational Chinese RNGOs are most likely to adopt different characteristics depending on their local context. For example, an RNGO may operate with a faith-background or secular organization within China, but may be a faith-permeated organization overseas for fundraising and recruiting purposes.

Some scholars maintain that RNGOs have innate strengths and contributions given their 'unique' social capital and appeal to certain donor audiences who sympathize with their religious mission (Moyer, Sinclair, \& Spaling, 2011). While secular organizations largely have to build their resource and support networks from comparatively smaller social capital bases, transnational religious organizations have these resource and support networks already established around the world through religious communities (Berger, 2003). For example, transnational networks between the Cantonese diaspora and Hong Kong are conveniently established with the flow of Chinese immigrants sharing a religion (e.g. Buddhism) with those in their home nation. In essence, though both secular NGOs and RNGOs operate under essentially the same political and legal frameworks in the public domain, the fact that RNGOs' mission moves beyond just 'reasoned' humanitarian values and is guided by a sense of obligation towards a divine higher power readily mobilizes those who share that mission (Berger, 2003; Clarke, 2006; Moyer et al., 2011). ${ }^{3}$

\section{Neo-institutional theory}

While Max Weber (1952) first theorized that organizational uncertainty could be resolved through rationalism, this notion has largely been challenged by neo-institutional theory. 
According to neo-institutional theorists, organizations that occupy a shared sector in times of uncertainty will eventually begin to copy one another due to coercive, mimetic, and normative isomorphic pressures regardless of the efficacy of such practices (DiMaggio \& Powell, 1983). ${ }^{4}$ In our context, we refer to factors and pressures that overtly or tacitly force RNGOs to adopt similar structures, forms, and behaviours.

Coercive pressures can be displayed by examining the impact of state regulation on the behaviour of an NGO. For example, Hasmath and Hsu (2014) point out that regulations in China forbid NGOs from conducting public fundraising. This ultimately forces NGOs to mostly rely on private and institutional donations (Deng \& Shieh, 2011), which are often accompanied by certain stipulations that alter NGOs' behaviour.

Mimetic pressures have a tendency to occur in an uncertain environment, where organizations will begin to copy successful models as a mechanism for coping with changing conditions (DiMaggio \& Powell, 1983; Meyer \& Rowan, 1991). By copying, NGOs are able to quickly establish legitimacy without having to build a repertoire of practices which can be time-consuming without necessarily leading to any tangible outcomes (Hasmath \& Hsu, 2014). This is particularly pronounced in the case of China where the environment for NGOs can oscillate depending on state behaviour (Hsu, 2011; Qi, 2011; Wen \& Cheng, 2012).

Normative pressures would eventually arise from a convergence of attitudes, norms, and approaches through the professionalization of NGOs-often the result of hiring practices that stress similar educational achievements, or inter-hiring between existing organizations (Hasmath \& Hsu, 2014).

The borrowing of isomorphism from neo-institutional theory as a heuristic to understand RNGO behaviour lies in the fact that it is able to explain why organizations adopt certain practices in environments where they have little power to reject the said practices. As Hasmath and Hsu (2014, p. 940) suggest, 'Chinese NGOs generally operate in a relatively singular institutional environment, whereby competing logics do not cause contestation; and thus, much variation in institutional designs'. By examining the isomorphic pressures of RNGOs, the study will uncover how RNGOs navigate the socio-political environment to maintain a continued and increasing presence in mainland China.

\section{Methodology and sample}

Semi-structured interviews were conducted with the leaders of eight RNGOs with transnational linkages operating in mainland China from May to July 2013 (see Table 1). Given the difficulty of gaining access to the knowledge of the internal operations of the said RNGOs, since the disclosure of confidential information may jeopardize their oft-covert operations in China, the sample selection was conducted through snowballing. Once the initial interview was held, we were referred to other RNGOs, revealing a network that we tapped into. The interviews were conducted face-to-face or via online audio chat, in English, Cantonese, and/or Mandarin Chinese. Interview transcripts were thereafter translated, transcribed, and coded to themes suggesting coercive, mimetic, and normative pressures. The coding process fragmented the interviews into separate categories forcing us to look at each detail. The synthesis involved piecing these fragments together to form a holistic and integrated explanation. Given the dearth of information on RNGOs in China, the conclusions are drawn primarily from the interview data we collected, which were supplemented by the broader literature on the subject matter. 
Table 1. Profile of RNGOs interviewed

\begin{tabular}{|c|c|c|c|c|c|c|c|}
\hline Name & $\begin{array}{l}\text { Typology of } \\
\text { religious } \\
\text { organization in } \\
\text { country of origin }\end{array}$ & $\begin{array}{l}\text { Typology of } \\
\text { religious } \\
\text { organization in } \\
\text { China }\end{array}$ & Type of work & NGO legal status in China & $\begin{array}{l}\text { Primary } \\
\text { religious } \\
\text { partner }\end{array}$ & $\begin{array}{l}\text { Government } \\
\text { partnership }\end{array}$ & $\begin{array}{c}\text { Country of } \\
\text { origin }\end{array}$ \\
\hline ATEC & Faith-permeated & Faith-permeated & $\begin{array}{l}\text {-Degree-granting } \\
\text { accredited USA } \\
\text { theological } \\
\text { seminary } \\
\text {-Training centre } \\
\text {-Short-term missions } \\
\text {-Publications }\end{array}$ & $\begin{array}{l}\text {-Unregistered in China but } \\
\text { formally accredited in } \\
\text { Asia and has church- } \\
\text { state partnership with } \\
\text { RAB }\end{array}$ & TSPC & Yes & USA \\
\hline BG & Faith-permeated & Faith-permeated & $\begin{array}{l}\text {-Broadcasting } \\
\text {-Training centre }\end{array}$ & -Registered in Hong Kong & House & No & $\begin{array}{l}\text { Canada with } \\
\quad \text { formal } \\
\text { global } \\
\text { network }\end{array}$ \\
\hline CFC & Faith-affiliated & $\begin{array}{l}\text { Faith-secular } \\
\text { partnership }\end{array}$ & $\begin{array}{l}\text {-Scholarships } \\
\text {-Funding support } \\
\text {-English camps } \\
\text {-Publications } \\
\text {-Water programmes } \\
\text {-Training } \\
\text { programmes } \\
\text {-Free health clinics } \\
\text {-Farmer education }\end{array}$ & -Registered with MCA & TSPC & Yes & USA \\
\hline $\begin{array}{l}\text { Dove's } \\
\text { wings }\end{array}$ & Faith-permeated & Faith-permeated & $\begin{array}{l}\text {-Training centres for } \\
\text { church leadership } \\
\text {-Summer camps } \\
\text {-Seminary } \\
\text {-Social work } \\
\text {-Publication }\end{array}$ & -Unregistered in China & $\begin{array}{l}\text { TSPC on } \\
\text { paper but } \\
\text { House on } \\
\text { the side }\end{array}$ & No & Canada \\
\hline
\end{tabular}


Table 1. Continued.

\begin{tabular}{|c|c|c|c|c|c|c|c|}
\hline Name & $\begin{array}{l}\text { Typology of } \\
\text { religious } \\
\text { organization in } \\
\text { country of origin }\end{array}$ & $\begin{array}{l}\text { Typology of } \\
\text { religious } \\
\text { organization in } \\
\text { China }\end{array}$ & Type of work & NGO legal status in China & $\begin{array}{l}\text { Primary } \\
\text { religious } \\
\text { partner }\end{array}$ & $\begin{array}{l}\text { Government } \\
\text { partnership }\end{array}$ & $\begin{array}{c}\text { Country of } \\
\text { origin }\end{array}$ \\
\hline MU & Faith-permeated & Faith-affiliated & $\begin{array}{l}\text {-Day care and nursery } \\
\text {-Health clinics } \\
\text {-Rural schools } \\
\text {-Hospital training } \\
\text {-Raising living } \\
\quad \text { standards }\end{array}$ & -Unregistered in China & None & No & Canada \\
\hline OJ & Faith-permeated & $\begin{array}{l}\text { Faith-secular } \\
\text { partnership }\end{array}$ & $\begin{array}{l}\text {-Orphanage } \\
\text {-Day care } \\
\text {-School } \\
\text {-Provide employment }\end{array}$ & -Registered with MCA & None & Yes & USA \\
\hline \multirow[t]{2}{*}{ TFC } & Faith-permeated & Faith-permeated & $\begin{array}{l}\text {-Training centres- } \\
\text { theological } \\
\text { training and } \\
\text { pastoring }\end{array}$ & -Unregistered in China & House & No & Canada \\
\hline & & & $\begin{array}{l}\text {-University } \\
\quad \text { fellowship } \\
\text { partnerships } \\
\text {-House seminaries } \\
\text {-Publication } \\
\text {-Work with } \\
\text { orphanages } \\
\text {-Training for } \\
\text { impaired }\end{array}$ & $\begin{array}{l}\text {-Registered in Hong Kong } \\
\text { and Canada }\end{array}$ & & & Hong Kong \\
\hline UFC & Faith-permeated & Faith-affiliated & $\begin{array}{l}\text {-Seminary } \\
\text {-Orphanages } \\
\text {-Vacation bible } \\
\text { school } \\
\text {-Health workshops } \\
\text { (e.g. sexually } \\
\text { transmitted } \\
\text { diseases [STDs]) } \\
\text {-Disaster relief }\end{array}$ & -Registered with MCA & TSPC & Yes & Canada \\
\hline
\end{tabular}


Secondary data from participant observation field notes informed the interview data. Archival documents were utilized, notably websites, brochures, presentation notes, and fund-raising documents provided by interview participants and other RNGO leaders who declined to partake in the interviews. In addition, field notes were taken at a conference of national missions attended primarily by Cantonese and Mandarin Chinese of an evangelical denomination in Canada in July 2013. The biennial conference averages approximately 1000 full-time attendees consisting typically of church leaders (e.g. clergy, elders, and deacons) within the same evangelical denomination. Several RNGOs promoted their work in China to mobilize funding and human resource support either through workshops, lectures, or information booths.

All the eight evangelical RNGOs would belong to the faith-permeated, faith-centred, or faith-affiliated categories. In other words, true to their evangelical nature, proselytization went in tandem with their health and education concerns in China. All the RNGOs in our sample shared several common features: They are headquartered in North America; they considered themselves successful in their educational work in China; they have established working relationships with local partners; and they are well established, having lasted for at least a decade in China.

Most RNGOs have operational budgets of over a million US dollars, with staffing consisting of full-time, part-time, and volunteer staff. All RNGOs in the sample were able to provide archival data such as brochures, pamphlets, or their official web page. Formal local partners of these RNGOs are either the government-sanctioned Three-Self Patriotic Churches (TSPC) ${ }^{5}$ or the illegal (but permissible) underground house churches. ${ }^{6}$ While one may expect that the rules of operation for partnering with TSPC and with house churches will vary greatly given their differing legal status, it ultimately depends on the local context (Hsu, 2012; Vala, 2012).

Geographically, the RNGOs in the sample are scattered across China, and vary greatly in their partners and target groups. However, given that the focus of the article is on negotiating the constrictive Chinese landscape, this geographical diversity is suitable. The RNGOs were similar in that they were all from the same evangelical Chinese social circle and thus will tend to have greater similarity since these RNGOs are more likely to communicate with one another in the first place. Nonetheless, given the usual problems of snowball sampling, that is, selection bias, the accounts of these organizations will likely have a lot of overlap given that they communicate with each other. In addition, they would have been filtered through a survivor bias, where they were all able to successfully negotiate the Chinese political landscape. This is acceptable as well since our interest is in their methods of adaptation and survival. While eight RNGOs is not a particularly exhaustive dataset, this article does not attempt to seek representativeness of the RNGO sector in China, but rather to elucidate the mechanisms that foster RNGOs' survival in Chinain other words, arriving at an explanation is the goal (Vaughn, 2009).

There are a few additional methodological limitations to this study. Foremost, a lack of diversity among interviewees makes it difficult for the research to lay broader claims. For example, accessing government agents, members of the TSPC and the house church, the local beneficiaries of RNGO services, and 'failed' RNGOs will paint a more holistic picture, as will narrowing down the RNGO groups to more specific characteristics (e.g. only RNGOs that serve the TSPC) and governmental level interaction (e.g. national, district, local). Further, comparative studies with secular NGOs, other types of RNGOs (e.g. 
Buddhism, Daoism, Catholic) and different types of Christian RNGOs (e.g. ecumenical, charismatic) will provide further insight on the theoretical framing of RNGOs in China.

\section{Findings and discussion}

\section{Coercive isomorphic pressures}

Several themes emerged when seeking to explain how RNGOs managed coercive isomorphic pressures. Specifically, they navigate the constrictive institutional environment by cooperating with local agents, fostering trust with the local government, and keeping a low profile.

\section{Cooperating with local agents}

All RNGOs in our sample had some form of cooperation with local agents. These local agents include leaders of schools, TSPC or house churches, university clubs, training centres (for Christian theological education), and seminaries (that teach Christian theology). Once these partnerships were formed, the spaces the Chinese partners possess provided room for RNGOs to proselytize. Specifically, the partnerships provided space for educational services such as giving workshops, teaching courses, and hosting summer camps (e.g. vacation Bible school) or English language camps, and for providing teachers to local schools. In general, the RNGOs chose between servicing either the TSPC or house churches, though there was occasional overlap depending on the local context. For example, in regions where the TSPC and the house churches are mutually congenial, they could share training sessions taught by the RNGOs.

Some RNGOs in our sample did not require Chinese partners in the first instance, and instead they became localized agents themselves, such as the case of Orphanage of Joy (OJ). As the OJ representative pointed out, the opportunity to become a localized agent is rare in China for two reasons: First, a RNGO purchasing land in China is considered a significant risk since the RNGO may lose everything if state policies shift to its detriment. As a result, most RNGOs who have a base in China rent office space. Second, urban centres such as Beijing or Shanghai will rarely grant land given there is a plethora of NGOs waiting to service their region. On the other hand, if NGOs were willing to build in more remote locations, they would be considered prestigious hallmarks for the local government. For instance, given the lack of NGO interest in its remote area of operation, OJ was able to successfully purchase and construct an orphanage village community on over 50 acres of land in the 1990s. OJ has since begun to expand its services to include a pre-school and an international school for local enrolment.

While OJ does not openly proselytize during official work hours, there are evening gatherings hosted on its campus where discussion of religion is permissible. Broadcasting Grace (BG) suggested that similar events occur when Christian businessmen from Hong Kong build factory villages that include churches and religious events as long as they occur within community grounds. All these efforts no doubt shine a positive light upon the local government and correspond with Vala's (2012) account of how local governments are amenable to RNGO aid and the religious mission, given the free, high-quality resources they provide. In other words, the availability of, and openness towards, RNGOs is contingent upon local contexts. 


\section{Fostering trust with the government}

For all the RNGOs in our sample the notion of relationships was a recurring theme. In essence, once an RNGO establishes a trusting relationship with the government, it is granted permission to do its work and even tap into the government's network of relations. Put differently, developing a trusting relationship with the government can provide a medium to manage (and potentially circumvent) coercive isomorphic pressures faced by RNGOs.

There are a number of considerations influencing the government's decision whether to trust the RNGOs interviewed. First, the history of the RNGO matters. For example, the government has a tendency to trust ethnic-Chinese-operated RNGOs rather than nonethnic-Chinese-based ones. For the government, there is the fear of Westerners mixing political agendas contrary to state philosophy into their religious work. Ethnic-Chineseoperated RNGOs are perceived (whether correctly or not) to be trustworthy given their ethno-cultural affinity. In turn, most of the RNGOs interviewed strictly employ ethnic Chinese over their Western counterparts, with some even overtly avoiding employing non-ethnic Chinese. In fairness, this in part can be attributed to the fact that RNGOs in China function primarily in a Chinese social network, where linguistic proficiency and an understanding of group norms are assets.

Furthermore, trust, knowledge, and awareness of RNGOs work in tandem with each other (Hasmath \& Hsu, 2015b; Hsu \& Hasmath, 2015). Once the RNGO begins to deliver quality services and has proven to the state that it is a trustworthy organization, the state will gradually loosen the reins and grant it further latitude to operate. The representative from American Theological Education Centre (ATEC) explained,

Right now we work at one of the seminaries where half of the program is provided by us. I think the Chinese government like us to do things this way. They want to first trust you and then let you do a little bit more and then eventually you can do whatever you like. I think this is their way of handling 'outsiders'.

The representative from Caring for China (CFC) echoed a similar sentiment,

The strategy that I adopted is to go slow and make sure that everywhere you go, you can build success stories. Where people can come in and will be able to see the program and see the actual impact, and then you can actually build much [stronger] government support for the long run.

Most of the interviewees who interacted with the state maintained that while they first had to report their lessons and itineraries to authorities, over time they no longer had to report their activities since they earned the state's trust. In the case of some RNGOs, the state agencies they interacted with actively promoted their work to other regions.

\section{Maintaining a low profile}

Maintaining a low profile was a common strategy. All the interviewees suggested that the government is aware of the religious activities that they are doing in China, since the government has 'informants' in both the TSPC and the house church networks. There was an acute awareness that if house churches and their constituents became too boisterous they 
would be suppressed by the state. Therefore, both the TSPC and house churches and the faith-permeated and faith-affiliated RNGOs involved sought a low profile. Some RNGOs like CFC and OJ mitigated this attendant problem by adopting a faith-secular partnership identity and thus, they register with the MCA, instead of SARA or the RAB.

When asked to elaborate on what it means to have a low profile, interviewees consistently reported several patterns: First, they should not promote their work publicly. If the RNGO is having a public speaker arrive to speak at the events of either the TSPC or house churches, there should not be a lot of fanfare or promotion of the event (e.g. posters, internet postings). In fact, sometimes the churches will announce a special guest the following week, without the benefit of additional information in order to not compromise the event. When RNGO members fail to maintain a low profile, for example, by proselytizing on the streets, the result was frequently deportation and blacklisting.

Second, while the RNGOs can teach religious material, they should refrain at all times from commenting on politics. This largely aligns with state policy of maintaining stability since the government perceives political critique as a destabilizing factor. For example, when an interviewee was teaching at a training centre, he was asked for his opinion about the Shouwang church's opposition against the central government. The interviewee replied directly by stating that he had no comment on the issue. Part of his thinking here was a recollection about the other RNGO leaders who critiqued the government's policy on religion in China and were quickly blacklisted from entering China.

Third, RNGOs are not to gloat about their work in China as a way of profiteering. ATEC, for example, began working in China in the late 1990s. For nine years, it remained in touch with SARA, but did not become involved with any projects. Over this period, ATEC garnered enough trust from SARA that it was invited to begin to teach in the official Chinese seminaries. The ATEC representative recounted that a government official told him that the reason they trusted ATEC was that they had read all their publications about China and noted in particular that they found ATEC especially trustworthy since it never posted pictures of its relationship with the government as a way to boast of its accomplishments in China to raise more funding. As a result, SARA stated on numerous public occasions that ATEC was an exemplary organization and granted them nationwide TSPC access, greatly enhancing ATEC's network.

It is worth noting that there is a strong temporal dimension to trust-building in ATEC's story. The ATEC interviewee stated that, prior to 1997, the overseas evangelical churches saw cooperation with the TSPC as a compromise of their faith mission and insisted that 'true Christians' work with the persecuted underground house churches. However, as the epistemological understanding of Christianity in China grew among the overseas churches along with the loosening of its religious constraints, many came to realize that a few compromises in cooperating with the state could open many doors and offer greater stability. Meanwhile, operating with house churches remains a risky proposition, especially if the house church gets shut down or the leaders develop cult-like characteristics.

Our ATEC interviewee stated that the SARA and RAB officials went from having few overseas RNGO partners to having too many suitors, citing that they sometimes need to meet ten RNGOs in a single day. Indeed, the attitudes of the overseas churches have shifted in the last decade from being clearly pro-house churches to a more nuanced understanding of RNGO-state cooperation. By now, ATEC is already an 'old friend' of SARA and $\mathrm{RAB}$ while the new suitors are vying for attention. Almost all the RNGOs summed it 
up with this saying, 'If there is guanxi (akin to social network capital) then there is no problem. If there is no guanxi, then everything is a problem!'

Fourth, the lexicon used by RNGOs should not alarm the state. Even though the state is likely aware of the RNGO's activities, the RNGO needs to creatively provide an alibi for the state to turn a blind eye. For example, RNGO leaders should not call themselves 'pastors', but instead go by 'teachers'. In email correspondence, which can be monitored by the state, words suggesting a Christian background are avoided.

Fifth, creative circumvention around religious policies allows RNGOs to not draw the ire of the local authorities. There is a near-universal hidden rule on proselytization in China that one cannot preach until one is asked about the religion. This rule was iterated on numerous occasions throughout the interviews. The manner in which this process was manifested in practice was discussed in detail by one interviewee:

A church can potentially have a small group gathering at the park ... 10-12 Christians will sing songs and afterwards they take out their Bibles and read it together. A stranger may come over and curiously engage in conversation. The first step is to tell the stranger your name and then ask this stranger his/her name. Once the stranger tells you their name they become 'friends' so to speak. Then they can ask their new friends to sit down and talk about the Bible. That's the way they bring a lot of people to the Church. The police do not bother them since they can always say, 'I talk to my friend about my belief. I'm not talking with a stranger because I know his name.'

By engaging in these practices RNGOs navigate the nuanced religious restrictions.

Finally, keeping a low profile is about being sensitive to the political situation. The Training for China (TFC) representative gave the example of when US President Barack Obama visited China in 2009, the police contacted the house churches informing them that they 'should lay low' for two weeks until the event was over. In practical terms, this meant keeping all gatherings to less than 30 people and avoiding all public spaces.

In summarizing why evangelical RNGOs need to retain a low profile, one interviewee eloquently stated:

The Chinese government is just like an old traditional Chinese father. If you save his face, he will let you do whatever you like. So just don't make him lose face and publicly embarrass him.

In other words, if RNGOs would like to proselytize, it is permissible so long as they observe the hidden rules.

\section{Mimetic isomorphic pressures}

Given the uncertainty of operating in China, RNGOs in our sample faced strong mimetic isomorphic pressures. Put differently, the RNGOs observed had similar patterns in dealing with this uncertainty by having staff exchanges and denominational supervisions and by tapping into transnational global platforms.

Transnational evangelical RNGOs experience a significant degree of staff exchange in their overseas communities that allows for the exchange of ideas. For example, 
the interviewee from BG used to be the head of TFC. When he switched from TFC to BG, he brought with him the networks he previously cultivated in China through TFC to BG-this includes staff, supporters, and donors. Concomitantly, TFC continued to use the networks established by the interviewee in China. Meanwhile, a senior pastor of an ethnic Chinese church that funded a number of missionaries abroad was brought in to run TFC. This staff exchange occurred in tandem with the rejection of individuals who did not share the same religious vision, thus greatly limiting the discrepant diversity of staff in RNGOs (Chan, 2008). In other words, transnational Chinese religious communities allow the exclusive flow of Christian staff across organizations to foster mimetic isomorphism and efficiently embed them into the network of relations in China.

Denominations often coordinate their respective churches and RNGOs in order to operate successfully in China. For example, Inspiration, an evangelical denomination in Canada, oversees almost 100 ethnic Chinese churches, comprising over 22,000 members. Along with the churches, Inspiration manages a number of RNGOs for the purpose of deploying missionaries. As the interviewee from United for China (UFC) suggests, the vision and mission of the RNGO is set by the denomination. In other words, Inspiration has the capacity to coordinate the resources of all the churches under its jurisdiction while maintaining a wide knowledge base with multiple RNGOs informing its grand strategy. In essence, an RNGO seen in China may be a single appendage of a much larger organization that may have multiple RNGOs sharing resources, staff, and strategy through the same denominational network. As a result, these RNGOs become similar since they receive resources, staff, and strategy from the same source while greatly enhancing their ability to survive.

Finally, and arguably most significantly, transnational global religious networks play a crucial role in allowing for the coordination and flow of ideas. The most prominent example for the ethnic Chinese network is the para-church organization International Chinese Christian Network (ICCN). While it has no direct authority, this organization serves as a platform for global dialogue for almost 9000 ethnic Chinese churches and an estimated 5.2 million ethnic Chinese Christians. ${ }^{7}$ Given that it is an ethnic Chinese network, it has ambitions for proselytizing in China and thus serves as a major conduit for resources, information, and strategy exchange among RNGOs who are affiliated with this network. The purpose of ICCN is to foster mimetic isomorphism among ethnic Chinese churches by sharing information and strategies. In this vein, there are a number of major advantages for an RNGO to be affiliated with ICCN. First, the tolerance and endurance of affiliated RNGOs is stronger as they have a transnational network from which to draw funding, resources, and ideas. The funding base of most RNGO interviewees is not constricted to one city or country; instead they draw funding from major concentrations of ethnic Chinese across the world. Second, one successful RNGO model working in China can disseminate information to ICCN that will then benefit all the other RNGOs as they also try to navigate the uncertainty of China. Third, given the shared vision and mission of these Chinese Christians, partnerships have a much greater success rate. For example, there is less fear of cannibalizing one another's RNGO since any RNGO's success means fulfilling the greater cause of expanding 'the Kingdom of God'. In short, RNGOs tapping into the ICCN network can enjoy many major benefits privy to their exclusive global community. 


\section{Normative isomorphic pressures}

According to the interviewees, the primary normative isomorphic pressure for evangelical RNGOs in China was the deliberate government promotion of professionalization in two fields. First, the government seeks to train Christian workers as a means of maintaining stability in both the TSPC and house churches. While it is easy to manage RNGO involvement in training the TSPC, the government largely turns a blind eye to the unregistered RNGOs that provide education to the house churches who have not threatened societal stability. Second, the local Chinese governments want to tap into free, high-quality resources despite the RNGOs' religious mission. In response, the RNGOs adopted a number of measures to rise to these challenges and solidify their legitimacy.

\section{Professionalization of Christian higher education}

RNGO participation in Chinese Christian higher education is the most illustrative example of the professionalization process. Since the CPC gained power in 1949, many Christian scholars were either killed or removed during purges like the Cultural Revolution, resulting in a 40-year gap in Christian higher education and leading to a dearth of qualified teachers. Interviewees involved in Christian higher education all shared the opinion that the government perceives a need for improved Christian higher education given the rapid rates of conversion occurring in China. Currently, each province has one TSPC-recognized seminary, totalling 21 nationally, but only Jinling Union Theological Seminary in Nanjing has the ability to train students for a master's degree. ${ }^{8}$ In many seminaries, often professors holding only undergraduate degrees teach undergrads, reflecting the low quality of theological education. Furthermore, some interviewees estimated a clergy to congregation ratio of 1:8000, an impossible ratio for a pastor to lead. That coupled with the decentralization of house churches (Koesel, 2013), whereby a single church cannot have more than 50 people and a pastor cannot oversee too many sites given travel distances leaves little wonder that the 1990s is deemed as the high point of house churches turning into cults. Therefore, the government's promotion of sound Christian higher education becomes synonymous with maintaining stability, preventing the birth of cults, ${ }^{9}$ containing and controlling negative Western influences, and creating 'good citizens'. All this results in a demand for transnational RNGOs to become involved.

RNGOs that serve the higher education needs of both the TSPC and the house churches get involved by tapping into their transnational networks. Large numbers of Western qualified educators, teaching in seminaries in Hong Kong, Canada, and the USA, are routinely flown over to China to teach at seminaries and the house church training centres.

Transnationalism creates a demand for more sophisticated pastors for the newly emerging 'city church', complicating the TSPC and house church dichotomy. These city churches are often called haigui churches, denoting the congregation as largely overseas returnees who have experienced Christianity abroad. These overseas returnees struggle to integrate into the 'doctrinally compromised' TSPC or largely low socioeconomic status rural house churches and seek more sophisticated theological teachings akin to those outside of China. As a result, higher quality theological training is in further demand.

For the above reasons, all the interviewees involved in Christian higher education have noticed a dramatic shift towards professionalization. Some noted that while they were able 
to teach random courses in the 1990s, where students just memorized and regurgitated the course content, the recent beneficiaries of China's educational reforms since the 1980s are now demanding a more sophisticated educational package that includes assessments, grades, and feedback. They even know which professors are good at which topic and make specific requests for teachers. Indeed, the overall improvement of the student base drives the demand for high-quality programmes.

There is also a movement towards credentialism. While the government can control the flow of people into the nation, by using, for example, the blacklist to exclude unwanted guests, it is much more difficult to block the flow of people leaving China to go to places such as Hong Kong. In several of the RNGOs that work with house churches and their respective house church seminaries, they organize workshops to be held in Hong Kong or adjacent regions like Taiwan, Singapore, and South Korea to give condensed courses suited for people who are visiting the nation under the guise of tourism. Given that these RNGOs have connections to accredited higher institutions throughout Asia, house church seminaries are now beginning to develop partnerships with these overseas institutions to provide joint degrees to participants who split the course load between China and abroad. Like higher education institutions around the world, the convenience of the Internet and online teaching also provides another avenue for formal educational opportunities. Since these partnerships with house churches are considered illegal, overseas seminaries can neither confirm nor deny the recipients of these degrees given the sensitive nature of the information.

Therefore, in terms of Christian higher education, the government recognizes the need for both the TSPC and house churches to have improved theological training as a means of maintaining stability, preventing the rise of illegal cults, and creating good citizens. Coupled with the aforementioned positive image of Christianity, the interviewee from Missions United (MU) maintains that the old adage, 'One more Christian means one less CPC member' has now changed to 'One more Christian means one more "good citizen"”.

\section{Holistic, integrated approach to proselytization}

When asked whether RNGO provision of services is contingent upon the availability of an audience receptive to proselytization, the representative from CFC describes the partnerships as a holistic, integrated approach, a 'two-legged' approach in which proselytization is done in tandem with educational services. This approach also applies to the RNGOs that fulfil humanitarian needs in addition to their educational work, such as MU. By providing clean water or the Montessori curriculum for the locals, MU creates opportunities to proselytize to locals in informal settings or in the church.

The local governments perceive RNGOs as useful sources of free resources. As mentioned earlier, institutions like OJ lend the local government credibility and legitimacy. Another example is MU's pre-school in Western China, which delivers and trains local teachers in the Montessori curriculum while also converting teachers to Christianity. The local government does not want to close the pre-school since it is well known for its high-quality education, to the extent that even government officials send their children to the pre-school. Essentially, the holistic, integrated approach is something that the government welcomes as long as the RNGOs submit to the CPC and thus do not destabilize society. 


\section{Conclusion}

This article has suggested that the resilience of RNGOs operating in China's institutional environment can be explained by three factors. First, these RNGOs are able to navigate coercive pressures by cooperating with local agents, fostering trust with the local state, and keeping a low profile. Second, RNGOs' practices often revolve around staff exchanges, denominational supervisions, and tapping into transnational global platforms. These mimetic activities suggest a strong organizational adaptability on the part of RNGOs to deal with the institutional complexities of China. Finally, RNGOs have engaged in a professional project that is, for the most part, promoted by the government. This, in turn, provides some form of predictability in RNGOs' activities, and further fosters trust on the part of the local state.

Suffice it to say, the three isomorphic pressures are well illustrated through the cases presented in this article and serve as effective analytical categories (while concomitantly interactive). An evident recurring pattern is that in the face of tightening state regulations (coercive pressure), organizations turned to exemplary organizations to copy (mimetic pressure) various strategies-one of them being professionalizing (normative pressure) to achieve increased legitimation from the perspective of the state.

While a number of studies have been done separately on religion and on the NGO sector in China, this article provides one of the first in-depth narratives into the little known field of RNGOs. This is especially rare given the reluctance of RNGOs to divulge information on their activities in China in light of the sensitive nature of what they do. With our sharp focus on how RNGOs survive in the heavily regulated civil society in China, we believe that these findings can inform studies on how RNGOs adapt in other heavily regulated jurisdictions (e.g. Hsu, Hildebrandt, \& Hasmath, 2015) and invite comparisons with other NGOs operating in sensitive issue areas (e.g. Hildebrandt, 2012). For the foreseeable future, RNGOs will continue to be among the most resilient social organizations outside the party-state structure, and their numbers and activities will expand. It is thus paramount that we probe further into their survival strategies in navigating an authoritarian socio-political environment.

\section{Acknowledgements}

We are grateful to Emily Hannum, Shawn Shieh, Thomas Breslin, and the two anonymous reviewers for their insightful comments and valuable feedback. An earlier version of this article was presented at the American Sociological Association Annual Meeting, 16-19 August 2014 (San Francisco, USA).

\section{Disclosure statement}

No potential conflict of interest was reported by the authors.

\section{Notes}

1. For example, the Taiping rebellion (1850-1864) started as a religious movement based on a modified form of Christianity. This took place shortly after the first Opium War (1839-1842), crippling the ruling Qing empire internally. 
2. The RAB generally lacks the resources to effectively keep up with daily administration, resulting in a visible disconnect between policies at the national level and practices at the local level (Vala, 2012).

3. Peggy Levitt (2007) presents the religious category 'religious global citizens' - that is, those who view the world not in secular terms (e.g. the state), but in a religious landscape. Ultimately, such global religious citizens believe that they are accountable to a divine higher power that justifies the circumvention and even the undermining of secular authority. This largely characterizes the resilience and risk-taking for the goal of proselytization demonstrated by the evangelical RNGO actors within our sample.

4. Note isomorphic pressures are not always empirically distinct from each other. Notwithstanding, we have followed DiMaggio and Powell's (1983) and Hasmath and Hsu's (2014) lead for analysing organizational (i.e. RNGO) behaviour in this fashion.

5. The Three-Self Patriotic Churches are officially sanctioned by the state to restrict foreign influences on church leadership, foreign financing, and foreign missionaries. The three 'self' are self-governance, self-support, and self-propagation; while 'patriotic' denotes the church's loyalty to China and the ruling $\mathrm{CPC}$.

6. Underground house churches are unofficial, unregistered assemblies of Christians who operate independently from state-control structures. Since members of the organization cannot independently own property, due to their legal status, they generally meet in private houses.

7. Data from ICCN suggest that $6-7 \%$ of the 80 million overseas Chinese are Christians; 5.2 million is a rough estimate of the midpoint: $6.5 \%$.

8. This exact number is contested by several interviewees, but the general consensus is in the 20 s for the government-sanctioned seminaries.

9. To illustrate the government's aversion to cults, after the 2008 Sichuan earthquake the government told the 'illegal' house churches to preach in the stricken areas because they needed to prevent cults from taking advantage of the situation and expanding. In fact, house churches' members providing relief were wearing apparel clearly identifying their church affiliation in public.

\section{References}

Berger, J. (2003). Religious nongovernmental organizations: An exploratory analysis. Voluntas: International Journal of Voluntary and Nonprofit Organizations, 14(1), 15-39.

Chan, S. (2008). Cross-cultural civility in global civil society: Transnational cooperation in Chinese NGOs. Global Networks, 8(2), 232-252.

Clarke, G. (2006). Faith matters: Faith-based organisations, civil society and international development. Journal of International Development, 18, 835-848.

Deng, G. (2010). The hidden rules of governing China's unregistered NGOs: Management and consequences. The China Review, 10(1), 183-206.

Deng, G., \& Shieh, S. (2011). An emerging civil society: The impact of the 2008 Sichuan earthquake on grassroots associations in China. The China Journal, 65, 181-194.

DiMaggio, P. J., \& Powell, W. W. (1983). The iron cage revisited: Institutional isomorphism and collective rationality in organizational fields. American Sociological Review, 48(2), 147-160.

General Office of the Central Committee of the Communist Party of China. (2011). Notice of 'Suggestions for doing a good job of resisting foreign use of religion to infiltrate institutes of higher education and preventing campus evangelism' (Document No. 18).

Hasmath, R. (2010). A comparative study of minority development in China and Canada. New York, NY: Palgrave Macmillan.

Hasmath, R., \& Hsu, J. (2008). NGOs in China: Issues of good governance and accountability. Asia Pacific Journal of Public Administration, 30(1), 1-11.

Hasmath, R., \& Hsu, J. (2014). Isomorphic pressures, epistemic communities and state-NGO collaboration in China. The China Quarterly, 220, 936-954.

Hasmath, R., \& Hsu, J. (Eds.). (2015a). NGO governance and management in China. New York, NY: Routledge.

Hasmath, R., \& Hsu, J. (2015b, November 19-21). Communities of practice and the NGO sector in China. Paper presented at Association for Research on Nonprofit Organizations and Voluntary Action Conference, Chicago, MA.

Hildebrandt, T. (2012). Development and division: The effect of transnational linkages and local politics on LGBT activism in China. Journal of Contemporary China, 21(77), 845-862. 
Hsu, C. (2011). Even further beyond civil society: The rise of internet-oriented Chinese NGOs. Journal of Civil Society, 7(1), 123-127.

Hsu, J. (2012). Layers of the state: Migrant organizations and the Chinese state. Urban Studies, 49(16), 3513-3530.

Hsu, J., \& Hasmath, R. (Eds.). (2013). The Chinese corporatist state: Adaptation, survival and resistance. New York, NY: Routledge.

Hsu, J., \& Hasmath, R. (2014). The local corporatist state and NGO relations in China. Journal of Contemporary China, 23(87), 516-534.

Hsu, J., \& Hasmath, R. (2015, August 22-25). Approaching maturity: The role of knowledge and professionalization in the development of Chinese NGOs. Paper presented at American Sociological Association Annual Meeting, Chicago, MA.

Hsu, J., Hildebrandt, T., \& Hasmath, R. (2015). 'Going out' or staying in? The expansion of Chinese NGOs in sub-Saharan Africa (Working Paper).

Koesel, K. J. (2013). The rise of a Chinese house church: The organizational weapon. The China Quarterly, 215, 572-589.

Levitt, P. (2007). God needs no passport: How immigrants are changing the American religious landscape. New York, NY: New Press.

Madsen, R. (2010). The upsurge of religion in China. Journal of Democracy, 21(4), 58-71.

Meyer, J. W., \& Rowan, B. (1991). Institutional organizations: Formal structure as myth and ceremony. In W. W. Powell \& P. J. DiMaggio (Eds.), The New Institutionalism in Organizational Analysis (pp. 44-62). Chicago, MA: University of Chicago Press.

Moyer, J. M., Sinclair, A. J., \& Spaling, H. (2011). Working for God and sustainability: The activities of faithbased organizations in Kenya. Voluntas: International Journal of Voluntary and Nonprofit Organizations, 23(4), 959-992.

Qi, M. (2011). Developing a working model for legal NGOs in China. Washington University Global Studies Law Review, 10(3), 617-639.

Shieh, S. (2013). NGO law monitor: China. Retrieved March 1, 2015, from The International Center for Not-forProfit Law website: http://www.icnl.org/research/monitor/china.html

Sider, R. J., \& Unruh, H. R. (2004). Typology of religious characteristics of social service and educational organizations and programs. Nonprofit and Voluntary Sector Quarterly, 33(1), 109-134.

Simon, K. (2013, August 16). Meaningful changes in the legal environment for civil society organizations (CSOs): Their relationship to larger trends in China's 'new' governance. Paper presented at Forum on NGO Governance and Management in China, Edmonton, Canada.

Thaut, L. C. (2009). The role of faith in Christian faith-based humanitarian agencies: Constructing the taxonomy. Voluntas: International Journal of Voluntary and Nonprofit Organizations, 20(4), 319-350.

Vala, C. T. (2012). The state-religion relationship. In R. Hasmath \& J. Y. J. Hsu (Eds.), The Chinese corporatist state: Adaptation, survival and resistance (pp. 102-119). London: Routledge.

Vaughn, D. (2009). Analytic ethnography. In P. Hedström \& P. Bearman (Eds.), The Oxford handbook of analytical sociology (pp. 688-711). Oxford: Oxford University Press.

Weber, M. (1952). The Protestant ethic and the spirit of capitalism. New York, NY: Scribner.

Wen, Y., \& Cheng, C. T. (2012). Resource platform, capacity building and social networking: A case study of NPI initiative. China Journal of Social Work, 5(2), 139-147.

Yang, F. (2012). Religion in China: Survival and revival under communist rule. Oxford: Oxford University Press. 